\title{
Physical Performance of Broiler Chickens Affected by Dietary Biological Additives
}

\author{
K.H. El-Kholy ${ }^{*}$, Samar M. Rakha and H.T. Tag El-Din \\ Poultry Production Department, Faculty of Agriculture, Damietta University, Damietta, 34518, Egypt. \\ *Corresponding author's Email: khelkholy@du.edu.eg; ORCID: 0000-0002-2562-2311
}

Received: 12 Jul. 2020

Accepted: 27 Aug. 2020

\begin{abstract}
The current study aimed to evaluate the effects of Saccharomyces cerevisiae yeast as a probiotic, compared to sodium butyrate as an organic acid on the productive performance of broiler chickens, with special attention to their economic efficiency. Therefore, 270 of one-day-old Hubbard broiler chickens were divided into 5 groups. The first group included chickens receiving basal ration without any treatment (and considered as a control group). The second group was composed of chickens treated with $0.2 \mathrm{~g} \mathrm{SB} / \mathrm{kg}$, the third group embraced chickens treated with $0.3 \mathrm{~g}$ $\mathrm{SB} / \mathrm{kg}$, the fourth group included chickens treated with $0.2 \mathrm{~g} \mathrm{SC} / \mathrm{kg}$, and the fifth group consisted of chickens treated with $0.3 \mathrm{~g} \mathrm{SC} / \mathrm{kg}$. The obtained results showed that administration of sodium butyrate or yeast showed a significant improvement of final body weight (BW), body weight change, feed conversion ratio and performance index from third to fifth weeks of age. Nevertheless, all treated groups showed an insignificant effect in feed intake, compared to control group. Furthermore, the dietary addition of Saccharomyces cerevisiae was detected more profitable than sodium butyrate addition. Accordingly, it can be concluded that sodium butyrate and yeast can be successively used as a natural substitute for antibiotic growth-promoting agents in the broiler chickens. Yeast can be considered as the most important alternative followed by sodium butyrate.
\end{abstract}

Keywords: Carcass, Economic efficiency, Hubbard; Productive, Sodium Butyrate, Yeast.

Abbreviations: SC: Saccharomyces cerevisiae; SB: sodium butyrate; BW: body weight; BWC: bodyweight change; FI: feed intake; FCR: feed conversion ratio; PI: performance index

\section{INTRODUCTION}

The poultry industry is now considered as one of the most important industries related to food security for peoples worldwide. One of the most important pillars of this industry is nutrition, which accounts for 75 to $80 \%$ of the industry's costs (El-Kholy et al., 2018). So, the concern was to devise strategies that support this pillar, and contribute to its development (Eltazi et al., 2014). Nowadays, one of the most important strategies is feed additives, because it is of the utmost importance in the poultry production (El-Kholy et al., 2019; Omar, 2020). Feed additives are aimed primarily for improving the physical performance (PR) of birds such as increasing body weight (BW), BW change and improving feed conversion ratios. In addition, they play a vital role in improving the productive and economic efficiency of poultry farms (Omar, 2020). In recent times, use of probiotics and organic acids were considered as natural feed additives used for broiler production. One of the probiotics is Saccharomyces cerevisiae (SC) which is produced from malted grains fermentation, also known as "baker's yeast", and it is most widely used as dietary growth promoters for animals (Gao et al., 2008; Omar, 2020). Moreover, SC is a rich source of protein, vitamin B complex, trace minerals and many other useful factors (Sun et al., 2020). Sodium butyrate (SB) is a recently used organic acid in broiler chickens' diet for realizing optimum performance (Awaad et al., 2019; Lan et al., 2020). It is rapidly absorbed to provide energy for the epithelial cells (Lan et al., 2020), and promote sodium and water absorption (Friedel and Levine, 1992). It increased the epithelial cell growth and the proliferation index in the intestinal crypts (Lan et al., 2020), also it had a trophic effect on the gut mucosa. Addition of these acidifiers broiler's diet enhanced nutrient utilization, growth and feed efficiency (Lan et al., 2020). Also, SB improved the balance of the intestinal microflora which led to a positive 
impact on the host's health (Candela et al., 2010). In poultry production, dietary acidifier addition did not gain as much attention as in swine production (Dehghani-Tafti and Jahanian, 2016). The previous studies on SC and SB in broiler chickens mainly focused on their phenotypic effects individually. So the aim of the present work was to study the effects of dietary administration of SC in comparison to SB on the growth performance in broiler chickens by estimation of both phenotypic changes in BW, BW change, feed intake, feed conversion ratio, relative growth rate and performance index, and economic efficiency.

\section{MATERIALS AND METHODS}

\section{Ethical approval}

The current study protocol used in this study was endorsed by the Animal Care and Use Committee of Damietta University, Damietta, Egypt.

\section{Materials}

The current experiment was conducted at a private commercial poultry farm under supervision of Poultry Production Department, Faculty of Agriculture, Damietta University, Damietta Governorate, Egypt. The period of study extended from twenty sixth of February, 2019 till second of March, 2019 to demonstrate the effects of dietary addition of probiotic (Saccharomycis cerevisiae; "SC") and organic acids (Sodium Butyrate, "SB") on some productive efficiencies of broiler chickens.

\section{Birds and experimental design}

Total of 270 one day-old Hubbard broiler chickens with an initial body weight (IBW, g) of $47.43 \pm 0.16$ gram supplied by commercial hatchery (El-Aml Hatching Company, Damietta) were used in this study. Chickens were individually weighed and assigned randomly to 5 equal experimental groups of 54 birds in each. Chickens of each group were subdivided into 3 replicates of 18 birds in each, and housed in floor pens. All birds were kept under the same managerial conditions. Feed and water were offered ad libitum throughout the experimental period (1 to 5 weeks of age). The first experimental group was fed with control diet while, the other four groups were fed with the basal diet with 0.2 and $0.3 \mathrm{~g}$ for each of SC and SB per kilogram body weight. For each treatment group, both levels of SC and SB were added to the basal diet, and subsequently mixed and stirred with a mixer. The birds were fed on starter and finisher ration according to NRC
(1994). The basal diets composition are tabulated in Table 1.

Table 1. Composition and calculated analysis of starter and finisher diets

\begin{tabular}{lcc}
\hline Ingredients & Starter (\%) & Finisher (\%) \\
\hline Yellow corn & 56.0 & 59.9 \\
Soy bean meal & 28.3 & 25.5 \\
Corn gluten meal & 10.0 & 08.5 \\
Vegetable oil & 01.5 & 02.5 \\
DI-Calcium phosphate & 01.7 & 01.7 \\
Limestone & 01.8 & 01.3 \\
L-lysine & 00.1 & 00.0 \\
Salt (NaCl) & 00.3 & 00.3 \\
Vitamins $\quad$ and Minerals & 00.3 & 00.3 \\
(Premix*) & & \\
Total & 100.0 & 100.0 \\
\hline Calculated analysis, ** & & \\
Crude protein, (CP, \%) & 23.06 & 21.10 \\
Metabolizable energy, & 3010 & 3106 \\
(Kcal/Kg) & & \\
Ether extract, (EE, \%) & 2.773 & 2.846 \\
Crude fiber, (CF, \%) & 3.554 & 3.409 \\
Calcium, (\%) & 1.143 & 0.949 \\
Available phosphorus, (\%) & 0.469 & 0.463 \\
Lysine, (\%) & 1.148 & 0.981 \\
Methionine, (\%) & 0.55 & 0.52 \\
Methionine + Cystine, (\%) & 0.855 & 0.789 \\
\hline
\end{tabular}

*The premix at 0.30 of the diet supplies, the following per kg of the diet: A, 1000 I.U., Vit D3 2000 I.U., Vit E, $10 \mathrm{mg}$, Vit K, $1 \mathrm{mg}$, Vit B1, $5 \mathrm{mg}$, Vit B2, $5 \mathrm{mg}$, Vit B6, $1.5 \mathrm{mg}$, Vit B12, $0.01 \mathrm{mg}$, folic acid $0.35 \mathrm{mg}$, Biotin, $0.05 \mathrm{mg}$, Pantothenic acid $10 \mathrm{mg}$, Niacin $30 \mathrm{mg}$, Coline $250 \mathrm{mg}$, $\mathrm{Fe}, 30 \mathrm{mg}, \mathrm{Zn}, 50 \mathrm{mg}, \mathrm{Cu}, 4 \mathrm{mg}$ and $\mathrm{Se}, 0.1 \mathrm{mg}$. **According to NRC, 1994.

\section{Management}

The birds were housed in a clean and well ventilated farm that was previously disinfected and prepared for receiving birds for the experiment. Birds were randomly housed in trial pens $(2 \mathrm{~m} \times 2.10 \mathrm{~m} \times 3 \mathrm{~m})$ with stocking density of $15 / \mathrm{m} 2$. The ambient temperature during brooding was $35{ }^{\circ} \mathrm{C} \pm 1$ at one-day-old of age, and gradually decreased to $25^{\circ} \mathrm{C} \pm 1$ on day 21 , and then kept constant. The birds were subjected to light schedule similar to commercial condition; 23 hours light from oneday-old birds until seventh day to give them enough time to find out feed and water, followed by 20 hours light from eighth day to the end of the experiment (35 days of age). Broiler chickens were vaccinated with mix (Infectious Bronchitis "IB" Ma5 + Newcastle clone 30) on day 7, and Gumboro D78 vaccine at 14 days of age, and they were replicated at 21 days of age. Finally, the birds were vaccinated against Newcastle (live clone 30 ) at 28 days of age. 


\section{Performance parameters}

The averages of body weight (BW, g), body weight change (BWC, g), feed intake (FI, g) and feed conversion ratio (FCR) which were evaluated according to the method described as follow: Average body weight (BW, g): The chickens were weighted individually at the beginning of the experiment, afterward chickens were weekly weighted and the live body weight change was taken; Body weight change (BWC, g): it was calculated as differences between two successive weights; Body weight change: W2 - W1; Where: W1 is the weight at any week, and W2 is the weight at the next week; Feed intake (FI, g): it was calculated by difference between the weight of the offered feed/week and the remained part, and then divided by the birds number in each group to measure the weekly FI per bird; FCR: it was calculated by dividing the amount of feed consumed $(\mathrm{g})$ during the week by the gain in weight (g) during the same week; Performance index (PI): it was calculated by adopting the below formula proposed by Bird (1955); PI: Body weight gain $(\mathrm{g}) \times$ FCR .

\section{Partial budget analysis}

The economics of feeding diet inclusion with SC and SB were calculated on the basis of overall cost of inputs, i.e. the cost of chickens, feeds, labor, medicines and other miscellaneous cost. Final live weight of the bird was considered for calculating the gross return per bird and net profit per bird.

\section{Statistical analysis}

All data were expressed as mean \pm standard error (SE) by one-way ANOVA with dietary treated addition as the main factor using statistical software of SPSS Version 25 (IBM SPSS, 2017) which used the general linear model (GLM) procedure based on the following model:

$Y_{i j}: \mu+T_{i}+e_{i j}$; where, Yij: Observation of the $j_{t h}$ chickens in the treatment $i ; \mu$ : Overall mean; $T_{i}$ : Effect of the treatments (i,: 1, 2, 3, 4 and 5); $\mathrm{e}_{\mathrm{ijj}}$ : Random error component. A probability of $\mathrm{P} \leq 0.05$ was required for statements of significance.

\section{RESEALTS}

\section{Performance parameters}

Effects of dietary biological addition on average body weight of broiler chickens:

Average body weight (BW) of broiler chickens as affected by SC and SB addition are presented in table 2 . The IBW of all chicken groups was nearly similar to each other $(47.53,47.37,47.53,47.37$ and 47.33 gram) indicating that birds were randomly distributed into the experimental treatments. During the starter period (0 to 2 weeks), dietary treatments did not affect $(\mathrm{P} \geq 0.05)$ chickens' body weight. At the end of 3 weeks of ages, BW for chickens only treated with SC groups (T4 and T5) significantly $(\mathrm{P} \leq 0.01)$ increased in comparison with the other groups. However, during the finisher (4 to 5 weeks) periods, dietary addition of $\mathrm{SC}$ and $\mathrm{SB}$, significantly $(\mathrm{P} \leq$ 0.05 ) increased the live BW. At the end of 5 weeks of age (marketing age), BW for groups fed with diets of T2, T3, $\mathrm{T} 4$ and $\mathrm{T} 5$ was higher $(0.1,8.4,14.7$ and 23.5 percent, respectively) as compared to those fed with control basal diet. Also, results reported in this study clearly indicated that, addition of $\mathrm{SC}$ had the significantly $(\mathrm{P} \leq 0.01)$ highest FBW as compared to SB in all experimental period except of 1 to 2 weeks which had no significant $(\mathrm{P} \geq 0.05)$ differences.

\section{Effect of dietary biological addition on average body weight change of broiler chicks}

Chickens treated with SC or SB $(0.2$ or $0.3 \mathrm{~g} / \mathrm{kg})$ showed a significant increase $(\mathrm{P} \leq 0.05)$ in the $\mathrm{BWC}$ in comparison with the control chickens for all experimental periods, except for the first and the second period (Table 3). Within the treated chickens, chickens treated with SC $(0.3 \mathrm{~g} / \mathrm{kg})$ showed the highest BWC followed by chickens treated with $\mathrm{SC}(0.2 \mathrm{~g} / \mathrm{kg})$ then chickens treated with SB from third to fifth weeks.

Effects of dietary biological addition on feed intake of broiler chicks

The effect of dietary addition of SC and SB on the FI of broiler chickens, as seen in table 4, showed an insignificant $(\mathrm{P} \geq 0.05)$ effect through the different weeks of age.

\section{Effects of dietary biological addition on feed conversion ratio of broiler}

Feed conversion ratio (FCR) was significantly $(\mathrm{P} \leq 0.01)$ improved from the third week until the end of experiment, and overall FCR at fifth week of age, and the value was being greater for $\mathrm{T} 1$ and $\mathrm{T} 2$ than $\mathrm{T} 3, \mathrm{~T} 4$ and $\mathrm{T} 5$ (Table 5). A significant improvement in FCR was recorded in the treated groups with $\mathrm{SC}$ or $\mathrm{SB}$ as compared to the untreated group. Within the treated chickens, chickens treated with $\mathrm{SC}(0.3 \mathrm{~g} / \mathrm{kg})$ showed the lowest FCR followed by chickens treated with SC $(0.2 \mathrm{~g} / \mathrm{kg})$, then chickens treated with $\mathrm{SB}$ at the third, fifth and 1 to 5 weeks of age. In general, high level addition of SC showed the best FCR compared to other treated groups. 


\section{Effects of dietary biological addition on performance index of broiler}

Chickens treated with SC or SB $(0.2$ or $0.3 \mathrm{~g} / \mathrm{kg})$ showed a significant $(\mathrm{P} \leq 0.01)$ increase in the PI in comparison with the control chickens (T1) for all experimental period except for the first and second period (Table 7). Also, PI showed an insignificant difference ( $\mathrm{P} \geq$ 0.05 ) among treatments in the first and second period. Within the treated chickens, chickens treated with SC $(0.3$ $\mathrm{g} / \mathrm{kg}$ ) showed the highest PI followed by chickens treated with $\mathrm{SC}(0.2 \mathrm{~g} / \mathrm{kg})$, then chickens treated with SB at third, fourth, fifth and 1 to 5 weeks of age. In general, high level addition of SC (T5) showed the best PI in compared to other treated groups.

\section{Partial budget analysis}

Data concerning economical evaluation are summarized in table 8 . The highest net revenue, economic efficiency and relative economic efficiency were obtained for T5 group followed by T4, T3, T2 compared to the lowest values which were detected in $\mathrm{T} 1$ (control group).

Table 2. Body weight of broiler chicks as affected by dietary addition of yeast and sodium butyrate during the experimental periods

\begin{tabular}{|c|c|c|c|c|c|c|}
\hline \multirow[b]{2}{*}{ Periods (Age/wk) } & \multirow{2}{*}{$\begin{array}{c}\text { Control } \\
\text { (T1) }\end{array}$} & \multicolumn{2}{|c|}{ Sodium Butyrate (SB, g/kg) } & \multicolumn{2}{|c|}{ Yeast (SC, g/kg) } & \multirow[t]{2}{*}{ Sig. } \\
\hline & & $\begin{array}{c}0.2 \\
(\mathrm{~T} 2) \\
\end{array}$ & $\begin{array}{c}0.3 \\
(\mathrm{~T} 3) \\
\end{array}$ & $\begin{array}{c}0.2 \\
(\mathrm{~T} 4) \\
\end{array}$ & $\begin{array}{c}0.3 \\
\text { (T5) } \\
\end{array}$ & \\
\hline Initial-Body Weight (BW) & $47.53 \pm 0.50$ & $47.37 \pm 0.50$ & $47.53 \pm 0.50$ & $47.37 \pm 0.17$ & $47.33 \pm 0.37$ & NS \\
\hline On $1^{\text {st }}$ wk & $146.80 \pm 0.71$ & $146.60 \pm 2.63$ & $147.53 \pm 1.99$ & $148.20 \pm 3.95$ & $155.60 \pm 1.60$ & NS \\
\hline On $2^{\text {nd }}$ wk & $353.63 \pm 3.19$ & $365.83 \pm 2.92$ & $361.43 \pm 5.78$ & $359.67 \pm 0.44$ & $358.20 \pm 3.86$ & NS \\
\hline On $3^{\text {rd }}$ wk & $680.67^{\mathrm{a}} \pm 5.29$ & $702.43^{\mathrm{a}} \pm 2.50$ & $697.87^{\mathrm{a}} \pm 8.08$ & $749.70^{\mathrm{b}} \pm 13.84$ & $802.30^{c} \pm 2.15$ & $* *$ \\
\hline On $4^{\text {th }}$ wk & $1111.53^{\mathrm{a}} \pm 0.09$ & $1259.27^{\mathrm{c}} \pm 11.79$ & $1212.03^{\mathrm{b}} \pm 0.42$ & $1227.87^{\mathrm{bc}} \pm 19.48$ & $1340.63^{\mathrm{d}} \pm 9.69$ & $* *$ \\
\hline On $5^{\text {th }}$ wk (Final BW) & $1501.37^{\mathrm{a}} \pm 1.02$ & $1678.67^{\mathrm{bc}} \pm 21.33$ & $1628.00^{\mathrm{b}} \pm 32.08$ & $1722.00^{\mathrm{c}} \pm 22.00$ & $1854.67^{\mathrm{d}} \pm 22.88$ & $* *$ \\
\hline
\end{tabular}

Table 3. Body weight change (of broiler chicks as affected by dietary addition of yeast and sodium butyrate during the experimental periods

\begin{tabular}{|c|c|c|c|c|c|c|}
\hline \multirow{2}{*}{ Periods (Age/wk) } & \multirow{2}{*}{$\begin{array}{c}\text { Control } \\
\text { (T1) }\end{array}$} & \multicolumn{2}{|c|}{ Sodium Butyrate (SB, g/kg) } & \multicolumn{2}{|c|}{ Yeast (SC, g/kg) } & \multirow[t]{2}{*}{ Sig. } \\
\hline & & $0.2(\mathrm{~T} 2)$ & $0.3(\mathrm{~T} 3)$ & $0.2(\mathrm{~T} 4)$ & 0.3 (T5) & \\
\hline On $1^{\text {st }}$ wk & $99.26 \pm 0.37$ & $99.23 \pm 2.89$ & $100.00 \pm 2.00$ & $100.83 \pm 3.79$ & $108.27 \pm 1.23$ & NS \\
\hline On $2^{\text {nd }}$ wk & $206.83 \pm 3.88$ & $219.23 \pm 5.47$ & $213.90 \pm 3.79$ & $211.47 \pm 3.79$ & $202.60 \pm 2.33$ & NS \\
\hline On $3^{\text {rd }}$ wk & $327.03^{\mathrm{a}} \pm 3.58$ & $336.60^{\mathrm{a}} \pm 5.41$ & $336.43^{\mathrm{a}} \pm 2.30$ & $390.03^{\mathrm{b}} \pm 13.58$ & $444.10^{c} \pm 2.82$ & $* *$ \\
\hline On $4^{\text {th }}$ wk & $430.87^{\mathrm{a}} \pm 5.38$ & $556.83^{\mathrm{d}} \pm 11.12$ & $514.17^{\mathrm{c}} \pm 8.35$ & $478.17^{\mathrm{b}} \pm 5.65$ & $494.13^{\mathrm{d}} \pm 5.58$ & $* *$ \\
\hline On $5^{\text {th }}$ wk & $389.83^{\mathrm{a}} \pm 0.94$ & $419.40^{\mathrm{a}} \pm 10.51$ & $415.97^{\mathrm{a}} \pm 32.19$ & $494.13^{\mathrm{b}} \pm 5.58$ & $514.03^{\mathrm{b}} \pm 20.30$ & $* *$ \\
\hline $1-5 \mathrm{wk}$ & $1453.82^{\mathrm{a}} \pm 20.00$ & $1631.29^{\mathrm{bc}} \pm 21.80$ & $1580.47^{\mathrm{b}} \pm 32.26$ & $1674.63^{\mathrm{c}} \pm 21.83$ & $1763.13^{\mathrm{d}} \pm 23.08$ & $* *$ \\
\hline
\end{tabular}

Table 4. Feed intake of broiler chicks as affected by dietary addition of yeast and sodium butyrate during the experimental periods

\begin{tabular}{|c|c|c|c|c|c|c|}
\hline \multirow{2}{*}{ Periods (Age/wk) } & \multirow{2}{*}{$\begin{array}{c}\text { Control } \\
\text { (T1) }\end{array}$} & \multicolumn{2}{|c|}{ Sodium Butyrate (SB, g/kg) } & \multicolumn{2}{|c|}{ Yeast (SC, g/kg) } & \multirow[t]{2}{*}{ Sig. } \\
\hline & & $0.2(\mathrm{~T} 2)$ & $0.3(\mathrm{~T} 3)$ & 0.2 (T4) & $0.3(\mathrm{~T} 5)$ & \\
\hline On $1^{\text {st }}$ wk & $159.33 \pm 3.05$ & $155.53 \pm 2.10$ & $155.60 \pm 2.12$ & $157.60 \pm 3.45$ & $158.77 \pm 4.72$ & NS \\
\hline On $2^{\text {nd }}$ wk & $400.80 \pm 9.01$ & $405.37 \pm 7.82$ & $394.10 \pm 2.63$ & $402.13 \pm 5.49$ & $407.87 \pm 4.84$ & NS \\
\hline On $3^{\text {rd }}$ wk & $648.60 \pm 7.64$ & $652.13 \pm 4.02$ & $637.77 \pm 19.27$ & $663.00 \pm 4.22$ & $653.63 \pm 4.96$ & NS \\
\hline On $4^{\text {th }}$ wk & $907.47 \pm 19.31$ & $895.23 \pm 30.51$ & $881.37 \pm 26.63$ & $907.13 \pm 37.28$ & $909.10 \pm 20.65$ & NS \\
\hline On $5^{\text {th }}$ wk & $1054.33 \pm 54.17$ & $984.67 \pm 15.76$ & $913.47 \pm 33.73$ & $986.00 \pm 2.87$ & $921.67 \pm 46.52$ & NS \\
\hline $1-5$ wk & $3170.53 \pm 39.65$ & $3092.93 \pm 32.23$ & $2982.30 \pm 81.52$ & $3115.87 \pm 45.68$ & $3051.03 \pm 35.60$ & NS \\
\hline
\end{tabular}

Sig: significant; NS: non-significant. Feed intake unit: g/chicks 
Table 5. Feed conversion rate of broiler chicks as affected by dietary addition of yeast and sodium butyrate during the experimental periods

\begin{tabular}{|c|c|c|c|c|c|c|}
\hline \multirow{2}{*}{ Periods (Age/wk) } & \multirow{2}{*}{$\begin{array}{c}\text { Control } \\
\text { (T1) }\end{array}$} & \multicolumn{2}{|c|}{ Sodium Butyrate (SB, g/kg) } & \multicolumn{2}{|c|}{ Yeast (SC, g/kg) } & \multirow[t]{2}{*}{ Sig. } \\
\hline & & $0.2(\mathrm{~T} 2)$ & $0.3(\mathrm{~T} 3)$ & $0.2(\mathrm{~T} 4)$ & 0.3 (T5) & \\
\hline On $1^{\text {st }}$ wk & $1.61 \pm 0.03$ & $1.57 \pm 0.04$ & $1.56 \pm 0.05$ & $1.57 \pm 0.05$ & $1.47 \pm 0.05$ & NS \\
\hline On $2^{\text {nd }}$ wk & $1.94 \pm 0.07$ & $1.85 \pm 0.03$ & $1.84 \pm 0.04$ & $1.90 \pm 0.06$ & $2.01 \pm 0.02$ & NS \\
\hline On $3^{\text {rd }}$ wk & $1.98^{\mathrm{c}} \pm 0.02$ & $1.94^{\mathrm{c}} \pm 0.04$ & $1.90^{\mathrm{b}} \pm 0.06$ & $1.70^{\mathrm{ab}} \pm 0.05$ & $1.47^{\mathrm{a}} \pm 0.01$ & $* *$ \\
\hline On $4^{\text {th }}$ wk & $2.11^{\mathrm{c}} \pm 0.05$ & $1.61^{\mathrm{a}} \pm 0.08$ & $1.71^{\mathrm{a}} \pm 0.04$ & $1.90^{\mathrm{b}} \pm 0.06$ & $1.69^{\mathrm{a}} \pm 0.05$ & $* *$ \\
\hline On $5^{\text {th }}$ wk & $2.70^{\mathrm{c}} \pm 0.14$ & $2.35^{\mathrm{bc}} \pm 0.09$ & $2.23^{\mathrm{ab}} \pm 0.24$ & $1.99^{\mathrm{ab}} \pm 0.02$ & $1.80^{\mathrm{a}} \pm 0.10$ & $* *$ \\
\hline $1-5 \mathrm{wk}$ & $2.07^{\mathrm{c}} \pm 0.03$ & $1.86^{\mathrm{b}} \pm 0.03$ & $1.85^{\mathrm{b}} \pm 0.09$ & $1.81^{\mathrm{ab}} \pm 0.01$ & $1.69^{\mathrm{a}} \pm 0.02$ & $* *$ \\
\hline
\end{tabular}

$\overline{\mathrm{a}, \mathrm{b}, \mathrm{c}}$ Means within the raw with different superscripts are significantly different $(\mathrm{P} \leq 0.05)$. Sig: significant; NS: non-significant; **: $(\mathrm{P} \leq 0.01)$.

Table 6. Performance index of broiler chicks as affected by dietary addition of yeast and sodium butyrate during the experimental periods

\begin{tabular}{|c|c|c|c|c|c|c|}
\hline \multirow{2}{*}{ Periods (Age/wk) } & \multirow{2}{*}{$\begin{array}{l}\text { Control } \\
\text { (T1) }\end{array}$} & \multicolumn{2}{|c|}{ Sodium Butyrate (SB, g/kg) } & \multicolumn{2}{|c|}{ Yeast (SC, g/kg) } & \multirow[t]{2}{*}{ Sig. } \\
\hline & & $0.2(\mathrm{~T} 2)$ & $0.3(\mathrm{~T} 3)$ & $0.2(\mathrm{~T} 4)$ & 0.3 (T5) & \\
\hline On $1^{\text {st }}$ wk & $9.15 \pm 0.11$ & $9.36 \pm 0.43$ & $9.50 \pm 0.41$ & $9.50 \pm 0.54$ & $10.63 \pm 0.41$ & NS \\
\hline On $2^{\text {nd }}$ wk & $18.28 \pm 0.78$ & $19.79 \pm 0.41$ & $19.64 \pm 0.76$ & $18.93 \pm 0.56$ & $17.80 \pm 0.34$ & NS \\
\hline On $3^{\text {rd }} w k$ & $34.33^{\mathrm{a}} \pm 0.64$ & $36.27^{\mathrm{a}} \pm 0.94$ & $36.91^{\mathrm{a}} \pm 1.55$ & $44.14^{\mathrm{b}} \pm 2.17$ & $54.51^{\mathrm{c}} \pm 0.36$ & $* *$ \\
\hline On $4^{\text {th }}$ wk & $52.82^{\mathrm{a}} \pm 1.14$ & $78.65^{\mathrm{cd}} \pm 4.64$ & $70.79^{b c} \pm 1.55$ & $64.82^{\mathrm{b}} \pm 0.95$ & $79.49^{\mathrm{d}} \pm 2.81$ & $* *$ \\
\hline On $5^{\text {th }}$ wk & $55.81^{\mathrm{a}} \pm 2.92$ & $71.65^{\mathrm{ab}} \pm 3.61$ & $74.93^{\mathrm{b}} \pm 9.28$ & $86.30^{\mathrm{bc}} \pm 1.62$ & $104.02^{c} \pm 7.07$ & $* *$ \\
\hline $1-5 \mathrm{wk}$ & $34.08^{\mathrm{a}} \pm 0.42$ & $43.14^{\mathrm{b}} \pm 1.46$ & $42.35^{\mathrm{b}} \pm 2.63$ & $44.74^{\mathrm{b}} \pm 0.57$ & $53.29^{c} \pm 1.77$ & $* *$ \\
\hline
\end{tabular}

${ }^{\mathrm{a}, \mathrm{b}, \mathrm{c}}$ Means within the raw with different superscripts are significantly different $(\mathrm{P} \leq 0.05)$. Sig: significant; NS = non-significant; **: $(\mathrm{P} \leq 0.01)$

Table 7. Partial budget analysis of broiler chicks as affected by dietary addition of yeast and sodium butyrate during 1-35 days

\begin{tabular}{|c|c|c|c|c|c|}
\hline \multirow{2}{*}{ Periods } & \multirow{2}{*}{$\begin{array}{c}\text { Control } \\
\text { (T1) }\end{array}$} & \multicolumn{2}{|c|}{ Sodium Butyrate (SB, g/kg) } & \multicolumn{2}{|c|}{ Yeast (SC, g/kg) } \\
\hline & & $0.2(\mathrm{~T} 2)$ & 0.3 (T3) & 0.2 (T4) & 0.3 (T5) \\
\hline Body weight change (kg) & 1.45 & 1.63 & 1.58 & 1.67 & 1.76 \\
\hline Price/kg body weight (LE) ${ }^{1}$ & 24.00 & 24.00 & 24.00 & 24.00 & 24.00 \\
\hline Selling price (LE/chick) & 34.8 & 39.12 & 37.92 & 40.08 & 42.24 \\
\hline Total feed intake/chick $(\mathrm{kg})$ & 3.17 & 3.09 & 2.98 & 3.12 & 3.05 \\
\hline Price/kg diet (LE) & 5.12 & 5.55 & 5.56 & 5.33 & 5.34 \\
\hline Total feed cost /chick (LE) & 16.23 & 17.15 & 16.57 & 16.63 & 16.29 \\
\hline Net revenue (LE) of each chick ${ }^{2}$ & 9.57 & 12.97 & 12.35 & 14.45 & 16.95 \\
\hline Economic efficiency $^{3}$ & 58.96 & 75.63 & 74.53 & 86.89 & 104.05 \\
\hline Relative economic efficiency ${ }^{4}$ & 100.00 & 128.27 & 126.41 & 147.37 & 176.48 \\
\hline
\end{tabular}

${ }^{1}$ The price was calculated on the base of ingredients price through the experimental period; LE: Egyptian pound. ${ }^{2}$ Net revenue of each chick $=[$ Selling price/chick - (Total feed cost/chick +9 Considering each chick coasted 9 LE included rent, labor costs, total veterinary management costs, mortality, all managerial efforts, etc.)]. ${ }^{3}$ Economic efficiency: (net revenue/ total feed coast/chicks) $\times 100 .{ }^{4}$ Relative economic efficiency of the control, assuming that the relative economic efficiency of the control: 100 .

\section{DISCUSSION}

In order to determine the productive effect of dietary addition of either SC or SB in broiler chickens was performed as natural and environmentally friendly alternatives. It was found that the birds treated with either SB or SC had a significant improvement effect on the broiler chickens' growth during all experimental period except for the first and second period. The insignificant differences in the results obtained during the first and second periods could be explained as the functionality of intestines of day-old chickens, and the activity of the digestive enzymes were not sufficiently developed (Ravindran, 2003). All these results were in agreement with findings of Sun et al. (2020) and Omar (2020) in broiler chickens. In contrary to the present results, no negative effect on BW, BWC and FCR were detected when broiler chickens had either supplements of SC (Eltazi et al., 2014; Devi et al., 2019) or organic acid (Denli et al., 2003; Lan et al., 2020). This might be due to kind and concentration of Saccharomyces. The result for FCR was in agreement with Mulatu et al. (2019) who 
reported a significant improvement in feed per gain ratio. In addition, many authors reported significant and better FCR on either SC (Mulatu et al., 2019; Sun et al., 2020) or $\mathrm{SB}$ addition in the diet of commercial broiler chickens (Awaad et al, 2019; Lan et al., 2020). In contrary to this result, Devi et al. (2019) and Al-Khalaifa et al. (2019) illustrated that dietary addition of SC had no impact on FCR.

In addition, Aghazadeh et al. (2012) recorded that dietary SB supplementation during the study period of 35 days had no effect on average FCR. These different results may be due to the available contents of SC or SB, animal age, health status and environment hygiene. The relative growth rate (RGR) result could be speculated that this was due to growth-stimulating effect of SC in broiler chickens as mentioned in the effects of SC in final BW and BWC (Tables 2 and 3). Higher PI was observed in group T5 which might be due to the effect of SC in final BW, and better FCR as compared to the other treatment groups in the current study. Comparable findings were discovered by Devi et al. (2019) stating the improvement in PI due to probiotic addition. The insignificant differences for FI in the present study were in line with the finding of Eltazi et al. (2014); Devi et al. (2019); Al-Khalaifa et al. (2019) for SC and Awaad et al. (2019) for SB. But these results disagreed with those obtained by Hernandez et al. (2013) who found that dietary addition of SC or SB, respectively, increased significantly the FI of broiler chickens.

In addition, the current study became in confrontation with those of Mulatu et al. (2019) who showed the lowest fed intake in all chickens received probiotic, and highest in the untreated group. So, the dietary addition of either SB or SC did not affect the FI of broiler chickens, but they increased the body weight gain significantly indicating an improved feed efficiency. This improvement in PR of broiler chickens in treated groups compared to control may be related to SC constituent with many metabolites like peptides, organic acids oligosaccharides, organic acids and flavor possibly some unidentified growth factors which were proposed to deliver useful responses in poultry production (Gao et al., 2008; Sun et al., 2020). These results also agreed with Markovic et al. (2009) demonstrating that dietary addition of SC improved broiler PR as SC improved the intestinal mucosal aspects, and produced new epithelial cells in the intestinal crypts, and migrated along the villi to the top. For instance, the significant $(P \leq 0.01)$ increase of $P R$ in SB groups as compared to the control one, may be discussed from the point of view that SB associated with direct or indirect modulation of insulin-like growth factor
(GF) production by insulin which can be related to impulse of muscle development (Mátis et al., 2019). The present results indicated an improvement in the net profit for chickens fed with diets containing of either SC or SB compared to those fed with diets with no additive (control). The present study was in agreement with those of Mulatu et al. (2019) and Devi et al. (2019) who indicated that the ration containing SC addition was potentially profitable than untreated one (control). Therefore, T5 appeared to be cost-effective in economic parameters used in the study. In the identical pattern, Omar (2020) verified that the supplementation of dried brewer's yeast as $0.4 \%$ for broiler breeds changed into more economically profitable than $0.2 \%$ and untreated. Also, Mátis et al. (2019) illustrated that dietary addition of sodium butyrate as organic acid gave the best economic profits compared to the control group (untreated) on broiler production.

\section{CONCLUSION}

From this trial, it was concluded that sodium butyrate can be used as a growth promoter in chickens as it improves the final body weight, body weight change, feed conversion ratio and relative growth rate by increasing intestinal absorption surface. But when sodium butyrate compared to yeast, yeast achieve the highest improvements. Also, the dietary addition of yeast and sodium butyrate for broiler breed was more economic than the control group.

\section{DECLARATIONS}

\section{Acknowledgements}

The authors gratefully acknowledge the excellent assistance of Prof. Dr. Ahmed Abdel-Khalek (Chief Researcher at Animal Production Research Institute, Cairo Egypt) for his kind provide the feed additives in the current study.

\section{Competing interests}

The authors declare that they have no conflict of interest.

\section{Authors contribution}

K.H.E., S.M.R. and T.H.T. developed the concept of the manuscript. K.H.E. wrote the manuscript. All authors checked and confirmed the final revised manuscript. 


\section{REFERENCES}

Aghazadeh AM and TahaYazdi M (2012). Effect of butyric acid supplementation and whole wheat inclusion on the performance and carcass traits of broilers. South African Journal of Animal Science, 42 (3): 241-248. DOI:https://doi.org/10.4314/sajas.v42i3.5

Al-Khalaifa H, Al-Nasser A, Al-Surayee T, Al-Kandari S, AlEnzi N, Al-Sharrah T, Ragheb G, Al-Qalaf G and Mohammed A (2019). Effect of dietary probiotics and prebiotics on the performance of broiler chickens. Poultry Science, 98: 4465-4479. DOI:https://doi.org/10.3382/ps/pez282

Bird HR (1955). Performance index of growing chicken. Poultry Science Journal, 34: 163-164. DOI:https://doi.org/10.3382/ps.0341163

Candela M, Maccaferri S, Turroni S, Carnevali P and Brigidi $P$ (2010). Functional intestinal microbiome, new frontiers in prebiotic design. International Journal of Food Microbiology, 140: 93-101. DOI: https://doi.org/10.1016/j.ijfoodmicro.2010.04.017

Dehghani-Tafti N and Jahanian R (2016). Effect of supplemental organic acids on performance, carcass characteristics, and serum biochemical metabolites in broilers fed diets containing different crude protein levels. Animal and Feed Science and Technology, 211: 109-116. https://doi.org/10.1016/j.anifeedsci.2015.09.019

Denli M, Okan F and Celik K (2003). Effect of dietary probiotic, organic acid and antibiotic supplementation to diets on broiler performance and carcass yield. Pakistan Journal of Nutrition, 2: 89-91. DOI:https://doi.org/10.3923/pjn.2003.89.91

Devi ND, Nizamuddin N and Vidyarthi VK (2019). Effect of dietary supplementation of probiotic on the performance of broiler chicken. Livestock Research International, 50(1): 62-67. DOI:https://doi.org/10.5455/ajvs.231428

El-Kholy KH, Hoda A Gad, Atef M, Reham AM Ali and Mervat N Ghazal (2018). Physiological and immunological performance of Domyati ducklings fed different levels of coconut oil. Egyptian Poultry Science Journal, 38 (3): 847-860. Available at: https://epsj.journals.ekb.eg/article_17108_93be91aa9647 1107ae16006255734738.pdf

El-Kholy KH, Tag El-Dein HT, Abd-El-Lateif AI and Aml I. Mekaouy (2019). Effects of dietary selenium sources on metabolic, enzymatic and immunoglobulin serum profiles in growing rabbits. Pakistan Journal of Nutrition, 18: 430-436. DOI: https://doi.org/10.3923/pjn.2019.430.436

Eltazi SM, Mohamed KA and Mohamed MA (2014). Response of broiler chicks to diets containing live yeast as probiotic natural feed additive. International Journal of Pharmaceutical Research Allied Science, 3: 40-46.
Available

at: http://repository.sustech.edu/handle/123456789/2898

Friedel D and Levine GM (1992). Effects of short chain fatty acids on colonic function and structure. Journal of Parenteral and Enteral Nutrition, 16: 1-4. DOI: https://doi.org/10.1177/014860719201600101

Gao J, Zhang HZ, Yu SH, Wu SG, Yoon I, Quigley J, Gao YP and Qi GH (2008). Effects of yeast culture in broiler diets on performance and immunomodulatory functions. Poultry Science, 87: 1377-1384. DOI: https://doi.org/10.1111/jam.14416

Hernandez J, Afanador G, Ariza-Nieto C and Avellaneda Y (2013). Evaluation of coated and powder sodium butyrate in diets for broilers reared with reused litter during a commercial production cycle. Journal of Animal Science, 91: 335-341. DOI: https://doi.org/10.1017/S0043933916000210

Lan RX, Li SQ, Zhao Z and An LL (2020). Sodium butyrate as an effective feed additive to improve growth performance and gastrointestinal development in broilers. Veterinary Medicine Science, 00: 1-9. DOI: https://doi.org/10.1002/vms3.250

Markovic R, Sefera D, Krstic M and Petrujikic B (2009). Effect of different growth promoters on broiler performance and gut morphology. Archives Medicine Veterinary, 41: 163-169. DOI: http://dx.doi.org/10.4067/S0301-732X2009000200010.

Mátis G, Petrilla J, Kulcsár A, Van den Bighelaar A, Boomsma B, Neogrády Z and Fébel H. (2019). Effects of dietary butyrate supplementation and crude protein level on carcass traits and meat composition of broiler chickens. Archives Animal Breeding, 62: 527-536. DOI:https://doi.org/10.5194/aab-62-527-2019

Mulatu K, Ameha N and Girma M (2019). Effects of feeding different levels of baker's yeast on performance and hematological parameters in broiler chickens. Journal World Poultry Research, 9: 38-49. DOI:https://dx.doi.org/10.36380/jwpr.2019.5

NRC (National Research Council) (1994). Nutrient requirements of poultry $\left(9^{\text {th }}\right.$ rev. Ed.) National Academy Press. Washington, D.C., USA pp. 26-34. DOI: https://doi.org/10.17226/2114

Omar MAE (2020). Economic evaluation of using dried Brewer's yeast as feed additives for two broiler breeds. Damanhour Journal of Veterinary Science, 3: 8-11. DOI: https://doi.org/10.5455/djvs.2019.65956

Ravindran V (2003). Development of digestive function in neonatal poultry: physiological limitations and potential. In Proc.: $15^{\text {th }}$ Annual Australian Poultry Science Symposium, Sydney, Australia, pp. 1-7. DOI: https://doi.org/10.1002/vms3.250

Sun Z, Wang T, Demelash N, Zheng S, Zhao W, Chen X, Zhen Y and Qin G (2020). Effect of yeast culture (Saccharomyces cerevisiae) on broilers: A preliminary 
El-Kholy et al., 2020

study on the effective components of yeast culture.

Animal,

10 ,

68 ;

DOI:

https://doi.org/10.3390/ani10010068 